\title{
タイプ $\mathrm{A}$ 行動特性の認知処理過程
}

\author{
- 二重課題遂行時の事象関連脳電位からの接近 - \\ $\bigcirc$ 伊藤 史 木田 光郎 \\ (愛知学院大学文学研究科) (愛知学院大学心身科学部) \\ key word：タイプA 行動特性, ERP-P3, 二重課題
}

タイプ A行動特性とは, 攻撃・敵意, 時間切迫, 競争, 精 力的行動などを特徽としている.このような特徴をもつタイ プ A 者の認知処理過程を明らかにするため, 藤井・木田 （1999）は, 聴覚刺激の弁別反応課題と視覚刺激のカウント 課題を用いた二重課題を設定し，標的刺激に対する事象関連 脳電位（ERP）の P3 振幅を, タイプ A-B で比較した. タイ プ A 群の P3 振幅は, 全ての課題条件で差はなかったが，タ イプ B群は課題負荷の増加によって減弱した.この結果から, タイプ A 者は, 課題負荷の増加により, 可能な限りの処理資 源を投入して課題を遂行するといった特徴を示唆した.一方, 行動指標の群差は，反応時間（RT）とカウント課題の誤反応 にはなかったが，主観的ストレス感を測定した NASA-TLX 得点で認められた。 タイプ A 群の NASA-TLX 得点は, 全て の課題条件で, タイプ $\mathrm{B}$ 群よりも高かったため, タイプ $\mathrm{A}$ 者 はストレスを感じやすいといった特徵も指摘している.

藤井・木田の研究では，P3 を刺激呈示後 300-600ms 区間 の最大陽性電位として同定した。しかし，多くの研究は，P3 が単一の陽性波ではなく, 複数の電位が重畳した成分である と論じている．赤嶺・木田（2004）は，画像刺激を用いた弁 別反応課題を設定し，標的刺激に対する P3 を検討した。 こ の結果，刺激呈示後 300-600ms 区間に 2 つ陽性波，Pz 優 勢で $380 \mathrm{~ms}$ 近傍に出現する初期 P3 と, Cz, Pz 優勢で $520 \mathrm{~ms}$ 近傍に出現する後期 P3 を観察した。 そして, 初期 P3 は刺激 評価, 後期 P3 は刺激評価後の処理（例えば, 反応選択の解 除，選択反応の正誤チェックなど）を反映する成分であるこ とを示唆した。本実験の目的は，二重課題遂行時のタイプ $\mathrm{A}$ 行動特性を, ERP-P3 振幅から検討することである. その際, P3 を2つの陽性波に分け，課題負荷の増加が，各成分の振幅 に与える影響を，タイプ A-B で比較することで，タイプ A 行動特性を明らかにする。

【方法】被験者: 大学生 20 名. (「日常行動質問表」(中野, 1995）を実施し, タイプ A群 10 名. タイプ B 群 10 名). 刺激 : 幾何学図形 (三角形, 菱形, 五角形, 六角形) と絵画 （女性，木，ライオン）を使用し，ディスプレイに $500 \mathrm{~ms}$ 呈示した．課題：RT 課題とカウント課題を設定した．RT 課 題は菱形に対して正確にできるだけ早くボタンを押すことで あり, カウント課題は絵画刺激の呈示回数を数えることであ る. カウント課題には, 女性刺激のみを数える $\mathrm{C} 1$ 課題と, 3 種の刺激を別々に数える C3 課題があった. 課題条件は, 課題負荷のない Control 条件, RT 課題のみを遂行する単一 課題条件の RT only 条件と， RT 課題とカウント課題を同時 に行う二重課題条件があり，二重課題条件には，課題負荷が 相対的に低い $\mathrm{RT}+\mathrm{C} 1$ 条件と, 課題負荷の高い $\mathrm{RT}+\mathrm{C} 3$ 条件 が設定された. 反応の測度: RT 課題の標的刺激に対する ERP が，課題条件ごとに算出された。また，主観的ストレス感を 測定するため, 各課題終了ごとに, NASA-TLXを実施した.

【結果と考察】

行動指標 : カウント課題と $\mathrm{RT}$ 課題の誤反応は, 両群で差は なかった， RT にも群差はなく，両群とも課題負荷の増加に
伴って遅延した. 主観的ストレス感は, タイプ B 群よりもタ イプ A 群で高く, タイプ A-B の差は, Control 条件と RT only 条件で大きかった。また, 両群とも, Control 条件より他の 3 条件で高かった。本研究で示された行動指標の結果は, 藤 井・木田（1999）の研究で示された結果と同じであり，タイ プ A 者がストレスを感じやすいこと, タイプ A 者の行動特徵 が，課題成績には反映されないことが示唆された。

ERP：ERP 平均波形を視察すると，2つの陽性波が観察さ れた。 これらの陽性波の出現潜時は, 赤嶺・木田（2004）の 研究で示された各成分の出現潜時と対応していた. そこで, $\mathrm{Pz}$ における $380 \mathrm{~ms}$ 近傍の陽性波を初期 P3（350-400ms 区 間の平均電位を初期 P3 振幅), $500 \mathrm{~ms}$ 近傍の陽性波を後期 P3（470-520ms 区間の平均電位を後期 P3 振幅）とした.

タイプ A 群の初期 P3 振幅は, RT only 条件よりも, 二重 課題条件で減弱したが，二重課題条件間に差はなかった。 タ イプ B 群の初期 P3 振幅は, RT only 条件で最も大きく, $\mathrm{RT}+\mathrm{C} 1$ 条件, $\mathrm{RT}+\mathrm{C} 3$ 条件の順で小さかった。本実験におけ る初期 P3 振幅の結果は, 藤井・木田（1999）が示唆したタ イプ A 者の課題遂行特徵(カウント課題の負荷が増加しても, $\mathrm{RT}$ 課題へ可能な限り処理資源を投入する）を支持するもの であった。 そして，この特徴が，刺激評価処理に観察される ことを示した. 一方, 後期 P3 振幅には, 群と課題条件によ る差はなかった. 初期および後期 P3 と課題成績からみられ るタイプ A 者の特徴は, 多くの処理資源を配分しても, それ が課題成績に反映されないことである. タイプ A 者は, 刺激 評価処理に多くの資源を配分するが，反応実行までの一連の 処理過程で，それを十分に利用できていないといえる.

Table 被験者群別の行動指標と, Pz における初期 P3 振幅 および後期 P3 振幅

\begin{tabular}{cccc}
\hline & & \multicolumn{1}{c}{ タイプA } & \multicolumn{1}{c}{ タイプB } \\
\hline \multirow{3}{*}{ 主観的 } & Control & $46.25(11.25)$ & $29.07(17.31)$ \\
\cline { 2 - 4 } & $\mathrm{RT}$ only & $52.50(6.99)$ & $43.24(15.03)$ \\
\cline { 2 - 4 } & $\mathrm{RT}+\mathrm{C} 1$ & $54.25(8.62)$ & $51.20(14.77)$ \\
\cline { 2 - 4 } & $\mathrm{RT}+\mathrm{C} 3$ & $58.42(10.68)$ & $55.74(11.43)$ \\
\hline \multirow{3}{*}{$\mathrm{RT}(\mathrm{ms})$} & $\mathrm{RT}$ only & $469.4(70.31)$ & $466.9(70.10)$ \\
\cline { 2 - 4 } & $\mathrm{RT}+\mathrm{C} 1$ & $529.2(67.37)$ & $502.1(74.61)$ \\
\cline { 2 - 4 } & $\mathrm{RT}+\mathrm{C} 3$ & $558.3(68.28)$ & $512.1(56.17)$ \\
\hline \multirow{3}{*}{ 初期P3振幅 } & Control & $0.44(2.53)$ & $1.77(4.03)$ \\
\cline { 2 - 4 } & $\mathrm{RT}$ only & $13.55(6.43)$ & $16.18(8.43)$ \\
\cline { 2 - 4 } & $\mathrm{RT}+\mathrm{C} 1$ & $11.48(6.39)$ & $13.60(10.11)$ \\
\cline { 2 - 4 } & $\mathrm{RT}+\mathrm{C} 3$ & $11.51(7.18)$ & $10.75(6.27)$ \\
\hline \multirow{3}{*}{ 後期P3振幅 } & Control & $1.35(2.02)$ & $1.59(3.12)$ \\
\cline { 2 - 4 }$(\mu \mathrm{V})$ & $\mathrm{RT}$ only & $16.79(5.92)$ & $15.99(7.66)$ \\
\cline { 2 - 4 } & $\mathrm{RT}+\mathrm{C} 1$ & $16.77(4.71)$ & $16.65(7.92)$ \\
\cline { 2 - 4 } & $\mathrm{RT}+\mathrm{C} 3$ & $17.09(5.34)$ & $16.49(5.79)$ \\
\hline
\end{tabular}

注 : ( ) 内は標準偏差

(ITO Fumi, KIDA Mitsuro) 